\title{
Financing public health in Europe
}

Bernd Rechel ${ }^{*}$, Helmut Brand, Martin McKee

${ }^{*}$ corresponding author

Bernd Rechel

Researcher

European Observatory on Health Systems and Policies

London School of Hygiene \& Tropical Medicine

15-17 Tavistock Place

London

WC1H 9SH

United Kingdom

Bernd.Rechel@Ishtm.ac.uk

Helmut Brand

Professor of European Public Health

Department of International Health

School for Public Health and Primary Care (caphri)

Faculty of Health, Medicine and Life Sciences

Maastricht University

P.O.Box 616

6200 MD Maastricht 
The Netherlands

Helmut.Brand@maastrichtuniversity.nl

Martin McKee

Professor of European Public Health

European Observatory on Health Systems and Policies

London School of Hygiene \& Tropical Medicine

15-17 Tavistock Place

London

WC1H 9SH

United Kingdom

Martin.McKee@lshtm.ac.uk

Manuscript under review at Gesundheitswesen

Character count: 25,015 (including spaces and references; excluding author information, abstracts and tables) 


\section{Abstract}

Aim: To ascertain the levels and mechanisms of funding public health in Europe.

Methods: A review of published and unpublished documents and expenditure data.

Results: Expenditure on public health in Europe is difficult to determine, but data from national health accounts suggest that it differs greatly across countries, both as a percentage of total health expenditure and per capita. Better data are urgently needed, given that a lack of sustainable, long-term funding may be the most significant barrier to public health programmes and interventions in Europe.

Conclusions: In view of the current economic crisis, it will be essential to safeguard financing for public health and to put it on a more sustainable basis.

Key words: public health, expenditure, financing, Europe 


\section{Zusammenfassung}

Ziel: Die Höhe und Mechanismen der Finanzierung öffentlicher Gesundheit in Europa festzustellen.

Methodik: Auswertung veröffentlichter und unveröffentlichter Literatur und Analyse von Gesundheitsausgaben.

Ergebnisse: Ausgaben zur öffentlichen Gesundheit in Europa lassen sich nicht zweifelsfrei ermitteln, aber, gemäß vorliegender nationaler Gesundheitskonten, variieren stark zwischen Ländern, sowohl als Anteil von Gesamtgesundheitsausgaben, als auch pro Kopf. Verlässlichere Daten sind dringend erforderlich, da das Fehlen einer nachhaltigen und langfristigen Finanzierung die größte Herausforderung von Programmen zur öffentlichen Gesundheit in Europa zu sein scheint.

Schlussfolgerung: Im Hinblick auf die gegenwärtige Wirtschaftskrise ist es wichtig, die Finanzierung von Programmen zur öffentlichen Gesundheit sicherzustellen und auf eine nachhaltigere Grundlage zu stellen.

Schlüsselwörter: öffentliche Gesundheit, Ausgaben, Finanzierung, Europa 


\section{Introduction}

The financing of public health has been described as something of a "black box" [1]. Research on health financing generally focuses on the financing of acute care and much less attention has been paid to how public health activities in Europe are being financed. One major reason for this may be the fact that expenditure on public health is difficult to capture, as much relevant action takes place outside the health system. The multiplicity of actors is another challenge, as is the fact that some costs (such as for occupational health) are often poorly accounted for [2]. This paper aims to shed light on the levels and mechanisms of funding public health in the WHO European region.

\section{Methods}

We conducted a documentary analysis of English-language sources relevant to the financing of public health operations in the WHO European region in April 2012. We reviewed two main types of documents. The first were sources available in the public domain. These included:

- the Health Systems in Transition (HiT) country profiles of the European Observatory on Health Systems and Policies [available at: http://www.euro.who.int/en/who-weare/partners/observatory/health-systems-in-transition-hit-series];

- self-assessments of public health capacities and services undertaken by WHO member states, supported by the WHO Regional Office for Europe and using a selfassessment tool structured around 10 essential public health operations (EPHOs). At the time of writing (April 2012), such assessments had been published in English on Estonia, Uzbekistan and South Eastern Europe;

- data on expenditure on public health and prevention published by WHO;

- articles published in international peer-reviewed journals and indexed on PubMed/Medline; in our search of article titles we combined three concepts, one related to public health (using the search terms "public health" OR "prevention" OR "health promotion"), one related to financing (using the search terms "fund" OR "finance*" OR "pay*" OR "allocate*" OR "expenditure"), and one related to the geographical region (using the search terms "Europe" OR "EU" OR the country names of the WHO European region). We excluded publications that did not deal 
with the financing of public health in Europe, were published before 2005, were not in English or did not contain an abstract.

The second type of documents were not available in the public domain. These included:

- an ongoing study on facets of public health by the European Observatory on Health Systems and Policies that will be published in 2013 [3];

- unpublished or draft self-assessments of public health capacities and services undertaken by WHO member states and written in English; these were provided to us by the WHO Regional Office for Bulgaria, Bosnia and Herzegovina, Croatia, Macedonia, Romania and Slovenia;

- the final report for an EU-funded study of public health capacity in the European Union, led by Maastricht University, that is envisaged to be published later in 2013; the study was based on information provided by key informants, complemented by focus group discussions of experts in each of the EU member states [4].

\section{Findings}

Several key dimensions of financing public health emerged. We will consider the expenditure devoted to public health and the mechanisms for funding public health activities in turn.

\section{Expenditure on public health}

As mentioned above, it is challenging to ascertain how much is spent on public health, due to the multiplicity of actors and sectors. In addition, until recently, the very definition of public health activities used to differ not only from one country to the next, but even between OECD, WHO and Eurostat [2, 5]. Some definitions included personal health services delivered by public health agencies, while others only included population-based services [5]. As a result, in 2010, data on expenditure on prevention and public health in Europe differed between OECD [6] and Eurostat [7].

Only in 2011 has a global standard of national health accounts been published [8]. For the first time, detailed guidance is available on what should and should not be included, based on explicit criteria. Prevention and public health services are defined as "services designed to enhance the health status of the population as distinct from curative services, which repair health dysfunction". Sub-components include maternal and child health, school health services, prevention of communicable or non-communicable diseases, and occupational 
health care. While this clarifies the boundaries considerably, and explicitly includes areas such as environmental surveillance for public health purposes, there are many areas that, in some countries, may come within the remit of public health, such as strategies to improve health through active transport programmes, that fall outside them [9].

Notwithstanding these limitations, available data from national health accounts provide the best possible estimates for internationally comparable national health expenditure. They are based on national reporting and published in the WHO Global Health Expenditure database. Where adjustments or estimates are required, these are validated by national Ministries of Health prior to publication [10].

Health accounts for the countries of the WHO European region indicate that expenditure on prevention and public health differs greatly as a percentage of total health expenditure (Table 1), ranging in 2010 from an implausible $0.62 \%$ in Italy to $8.17 \%$ in Romania [11]. This suggests considerable room for increased financial allocations to public health in many European countries, but also that some data (such as for the extremes Italy or Romania) may not be entirely accurate. Unsurprisingly, in the study on public health capacity in the EU, the lack of adequate resource provision was identified as often the most significant barrier to the effective implementation of public health programmes and interventions [4].

[Table 1 around here]

It is also important to note that levels of total health expenditure per capita differ markedly across Europe. In per capita terms, and adjusted for purchasing power parity (PPP), expenditure on prevention and public health in 2010 differed by a factor of more than 50 , from US\$ 3.6 in Tajikistan to US\$ 193.8 in the Netherlands (Table 2). However, it is important to note that factors for calculating Purchasing Power Parity focus on internationally traded goods; these corrections must thus be interpreted with care [12].

[Table 2 around here] 


\section{Mechanisms for financing public health in Europe}

Just as with the financing of health care in general, arrangements for financing public health vary greatly within Europe. An overview of the main mechanisms, as well as illustrative examples, is given below.

\section{Funding mechanisms}

Many public health activities are linked to the health care system and are influenced by the way that these are financed. Consequently, they vary between systems funded from taxation and social insurance and, when tax-based, which administrative level pays for public health activities. It has been suggested that countries with social health insurance models of funding have less comprehensive national public health activities than those with tax-based systems, due to the more population-oriented approach of the former [2]. However, financing arrangements are much more complex than this dichotomy suggests and also differ according to the type of activity.

In some countries, such as France [13], the multiplicity of funding sources was noted as a weakness confronting disease prevention and health promotion activities. Unstable funding was also noted in the countries of South Eastern Europe, where funding is often allocated on an ad hoc basis, sometimes relying on international agencies, leading to haphazard planning and a lack of overall strategies [14]. A disconnect with outputs has been identified as another weakness [15].

While in some countries with health insurance funds, these funds support public health activities, often the public health function is funded separately, from taxation. Germany is an example of the former. Most preventive measures aimed at individuals, such as immunizations, screening programmes and health check-ups are carried out by office-based physicians and included in the sickness funds' benefit package, which also cover populationbased health promotion activities [16]. In Croatia too, the national vaccination programme is completely covered by the Health Insurance Institute [17].

In contrast, the Netherlands, which like Germany largely relies on health insurance to pay for curative health services, funds major prevention programmes from general taxation [18]. The countries of central and eastern Europe and the former Soviet Union also use tax-based budgetary funding to fund public health services [19], with few significant reforms since the fall of communism [1]. However, even in these countries a mix of public financing sources seems to be common, such as in the Czech Republic, where preventive services provided by GPs (vaccinations and screening) are covered by the benefit package of the health 
insurance fund, while the Ministry of Health provides direct, tax-based funding for public health services, such as specialized health programmes [20]. Austria also relies on a mix of financing sources; the two-thirds of the budget for vaccines is from the federal government, and a sixth each is paid each by the Länder (regions) and the social health insurance institutions [21]. In south-eastern Europe, funding for core public health functions, such as vaccination, typically comes directly from central government [14].

Those countries with tax-based funding for public health activities differ with regard to which level of government is involved. In general, this follows constitutional arrangements, with sub-national levels playing an important financing role in federal systems, with implications for geographical equity. However, responsibilities are often shared. In Finland, for example, municipalities are responsible for funding immunizations [22]. In Denmark, vaccination programmes are also financed by the regions [23], while in Belgium two thirds of vaccination costs are borne by the federal government and one third by the communities [24]. In almost all countries of central and eastern Europe and the former Soviet Union, tax-based funding comes from the central government, but there are exceptions, such as Poland, which has introduced co-funding from the local government [19]. The "Öffentliche Gesundheitsdienst" in Germany is a state-run system of public health offices run and funded by cities and municipalities. However, capacity is often limited as a consequence of budgetary shortfalls in some cities and municipalities [4].

\section{Mechanisms for reimbursing providers}

In many European countries (including Austria, the Netherlands, Denmark, the Czech Republic, and the United Kingdom), payment of primary health care providers involves a mixed system, including, in varying combinations, the number of registered patients (capitation), fee-for-service, payment for implementation of certain programmes, and payment for performance $[25,26]$. Performance or programme-based payment may involve targets, some of which may be related to public health activities. In Sweden for example, some county councils use a small performance-based element of payment $(2-3 \%$ of the total payment), that is partly dependent on the provision of preventive services [27]. In South East Europe, several countries have adopted such combined payment systems [28]. In Montenegro, $10 \%$ of earnings of primary health care teams are directly related to implementing prevention programmes [29]. One model that has attracted much interest is the Quality and Outcomes Framework introduced for family medicine in the United Kingdom in 2004 [25]. This framework allocates extra funds to general practices if they meet a range of criteria, some of which relate to disease prevention [30]. In Estonia, GPs receive specific 
incentives to offer preventive services, including counselling patients on medical and behavioural risks [31, 32]. While in some countries, personal preventive services are covered by the main public financing body, as in Estonia by the national health insurance fund [32], in others, such as Armenia [33], there are no incentives for physicians to engage in prevention.

\section{Financing health promotion}

The challenge of putting health promotion activities on a sustainable financial basis has been noted in several countries. The problem is particularly acute where funding mechanisms are not linked to health financing as a whole, but rather ad hoc or based on external funding [14, 34]. Several countries, including Austria and Switzerland, have established foundations for health promotion $[35,36]$. Both foundations pursue co-financing, which may have increased health promotion expenditure from other sectors [36]. Some of the most successful health promotion activities have been implemented in the Nordic countries [37], such as the oftencited North Karelia project in Finland [22]. In Central and Eastern Europe, health promotion was underdeveloped in the Soviet period [35] and health promotion tends remain in many countries one of the most underdeveloped and underfinanced domains of public health [38].

\section{Ear-marked taxes}

Some countries have started to ear-mark the revenue derived from taxes on products detrimental to health for public health activities. An example is Austria, where revenue from tobacco tax has to be used for preventive check-ups and health promotion measures [21]. Bulgaria has committed to devoting $1 \%$ of resources received in the national budget from excise duties on tobacco and alcoholic beverages are used for programmes addressing these risk factors and illicit drugs [14]. With the exception of taxes on tobacco and alcohol, however, the use of fiscal instruments for public health is not yet widespread [39].

\section{Responding to the economic crisis}

As a result of the current economic crisis, the financing of public health is in danger in many countries, as the long-term benefits of public health interventions are often overlooked [40]. Many structures for delivering public health operations in Europe are already facing substantial cutbacks and public health programmes and interventions in several countries, including Bulgaria, Latvia and the United Kingdom, have been scaled down [4]. One extreme example is Latvia, where, until 2009, the lead organization for public health was the Public Health Agency. In September 2009, it was closed down. In 2010, the government 
discontinued provision of public health promotion activities to the population [4], although this is not yet reflected in expenditure data as shown in Table 1.

Other countries have taken proactive action to sustain public health in times of crisis. The Austrian Health Promotion Foundation, for example, has since 2009 offered full financing to projects by small- and medium-sized companies, as these were perceived to be most affected by the economic crisis [36]. It is also noteworthy that the share of total health expenditure spent on public health has changed little in most countries in the years 20082010 (Table 1).

\section{Discussion}

We hope our findings stimulate discussion about the need for more reliable information on levels and mechanisms for funding public health in Europe. While our review provided insights into what information is currently available, major gaps remain. The first is that available data on expenditure on public health is not entirely reliable. This has to do with definitional challenges, but also with the fact that not all public health activities are captured in national health accounts. To the degree that data exist, a large variation in expenditure on public health can be found, suggesting that the long-term benefits of investing in public health are still not widely accepted.

There is also a large variation in mechanisms for funding public health. These are partly related to the way that political systems are decentralized, and sub-national levels play an important financing role in federal or decentralized systems. However, this carries the danger of exposing public health to different funding levels across sub-national units.

Overall, there usually exists a mixture of funding sources, with no one best way of addressing this issue. Where many agencies are involved, the integration can become a challenge. One of the issues gaining increasing attention is the provision of public health activities by primary care physicians and nurses, which can be incentivized through different forms of bonus systems.

The financing of health promotion activities is another area gaining attention, especially with regard to sustainable, long-term funding. A promising model seems to be the establishment of foundations for health promotion, which seem to improve sustainability and intersectoral revenue collection. Some countries are also leading the way with ear-marked taxes for public health activities, but, overall, and with the exception of alcohol and tobacco, the use of fiscal instruments for public health is not yet widespread. 
Finally, the impact of the global economic crisis on funding public health is beginning to be felt. In some countries, such as Latvia, public health has almost completely been dismantled. Other countries are facing severe budget cutbacks. A key finding is that the available data indicate that the share of total health expenditure spent on public health has not declined since 2008. This suggests that, where the political will exists, funding for public health can be maintained and even increased. It will be essential to continue monitoring of expenditure on public health, as newer data become available. It will also be important to place a higher priority on publishing data in a timely manner; it seems strange, in a rapidly moving global environment, to be making decisions on data that are almost three years out of date. 


\section{References}

1. Duran, A. and J. Kutzin, Financing of public health services and programmes: time to look into the black box, in Implementing Health Financing Reform. Lessons from countries in transition, J. Kutzin, C. Cashin, and M. Jakab, Editors. 2010, World Health Organization, on behalf of the European Observatory on Health Systems and Policies: Copenhagen. p. 247268.

2. Allin, S., et al., Making decisions on public health: a review of eight countries, 2004, World Health Organization on behalf of the European Observatory on Health Systems and Policies: Copenhagen.

3. Rechel, B. and M. McKee, eds. Facets of public health in Europe. 2013, World Health Organization Regional Office for Europe, on behalf of the European Observatory on Health Systems and Policies: Copenhagen.

4. Aluttis, C., et al., Reviewing Public Health Capacity in the EU, 2012, Maastricht University: Maastricht.

5. Sensenig, A.L., Refining Estimates of Public Health Spending as Measured in National Health Expenditures Accounts: The United States Experience. J Public Health Management Practice, 2007. 13(2): p. 103-114.

6. OECD, Health Data 2011, Statistics and Indicators, 2011, OECD: Paris.

7. Eurostat,

Database [http://epp.eurostat.ec.europa.eu/portal/page/portal/health/public health/data public he alth/database, accessed 29 April 2012], 2011.

8. OECD, Eurostat, and WHO, A System of Health Accounts. 2011 edition [http://www.who.int/nha/sha revision/sha 2011 final1.pdf, accessed 28 January 2013], 2011, OECD: Paris.

9. de Bekker-Grob, E., et al., Towards a comprehensive estimate of national spending on prevention. BMC Public Health, 2007. 7(252).

10. WHO, General statistical procedures used to construct WHO health expenditure database [http://apps.who.int/nha/database/ResourcesPage.aspx, accessed 28 January 2013], 2012, World Health Organization: Geneva.

11. WHO, Health Expenditure database [http://apps.who.int/nha/database/DataExplorer.aspx?ws=0\&d=1, accessed 20 May 2012], 2012, World Health Organization: Geneva.

12. Callen, T., Purchasing Power Parity: Weights Matter, 2012, IMF: Washington DC.

13. Sandier, S., V. Paris, and D. Polton, Health care systems in transition: France, 2004, WHO Regional Office for Europe on behalf of the European Observatory on Health Systems and Policies: Copenhagen.

14. WHO, Evaluation of public health services in south-eastern Europe, 2009, World Health Organization Regional Office for Europe: Copenhagen.

15. WHO, Evaluation of public health services in Slovenia, 2009, World Health Organization Regional Office for Europe: Copenhagen.

16. Busse, R. and A. Riesberg, Health care systems in transition: Germany, 2004, WHO Regional Office for Europe on behalf of the European Observatory on Health Systems and Policies: Copenhagen.

17. WHO, Evaluation of Public Health Services in South-eastern Europe. Croatia. Draft National Report, 2007, World Health Organization Regional Office for Europe: Copenhagen.

18. Schäfer, W., et al., The Netherlands: Health System Review. Health Systems in Transition, 2010. 12(1). 
19. Gotsadze, G., et al., Reforming sanitary-epidemiological service in Central and Eastern Europe and the former Soviet Union: an exploratory study. BMC Public Health, 2010. 10(440).

20. Bryndova, L., et al., Czech Republic: Health system review. Health Systems in Transition, 2009. 11(1): p. 1-122.

21. Hofmarcher, M. and H.-M. Rack, Austria: Health system review. Health Systems in Transition, 2006. 8(3): p. 1-247.

22. Vuorenkoski, L., P. Mladovsky, and E. Mossialos, Finland: Health system review. Health Systems in Transition, 2008. 10(4): p. 1-168.

23. Strandberg-Larsen, M., et al., Denmark: Health system review. Health Systems in Transition, 2007. 9(6): p. 1-164.

24. Gerkens, S. and S. Merkur, Belgium: Health system review. Health Systems in Transition, 2010. 12(5): p. 1-266.

25. Katic, M., D. Jurkovic, and V. Juresa, The Combined Way of Paying Family Medicine in Croatia, in Health Reforms in South East Europe, W. Bartlett, J. Bozikov, and B. Rechel, Editors. 2012, Palgrave Macmillan: Houndmills. p. 193-206.

26. Fujisawa, R. and G. Lafortune, The Remuneration of General Practitioners and Specialists in 14 OECD countries: What are the Factors Influencing Variations across Countries?, 2008, OECD: Paris.

27. Anell, A., A. Glenngård, and S. Merkur, Sweden: Health system review. Health Systems in Transition, 2012. 14(5): p. 1-159.

28. Rechel, B., J. Bozikov, and W. Bartlett, Lessons from Two Decades of Health Reforms in South East Europe, in Health Reforms in South East Europe, W. Bartlett, J. Bozikov, and B. Rechel, Editors. 2012, Palgrave Macmillan: Houndmills. p. 229-239.

29. Ostojic, D. and R. Andric, Reforms of the Organization and Financing of Primary Health Care in Montenegro, in Health Reforms in South East Europe, W. Bartlett, J. Bozikov, and B. Rechel, Editors. 2012, Palgrave Macmillan: Houndmills. p. 207-217.

30. Boyle, S., United Kingdom (England): Health system review. Health Systems in Transition, 2011. 13(1): p. 1-486.

31. Koppel, A., et al., Estonia: Health system review. Health Systems in Transition, 2008. 10(1): p. 1-230.

32. Koppel, A., A. Leventhal, and M. Sedgley, eds. Public health in Estonia 2008. An analysis of public health operations, services and activities. 2009, World Health Organization Regional Office for Europe: Copenhagen.

33. Armenian, H.K., et al., Analysis of public health services in Armenia, 2009, American University of Armenia: Yerevan.

34. Bayarsaikhan, D. and J. Muiser, Financing health promotion, 2007, World Health Organization: Geneva.

35. Saltman, R., et al., Assessing health reform trends in Europe, in Health Systems, Health, Wealth and Societal Well-being, J. Figueras and M. McKee, Editors. 2012, Open University Press: Maidenhead. p. 209-246.

36. Schang, L., K. Czabanowska, and V. Lin, Securing funds for health promotion: lessons from health promotion foundations based on experiences from Austria, Australia, Germany, Hungary and Switzerland. Health Promot Int, 2011. Apr 5. [Epub ahead of print].

37. Glenngård, A., et al., Health Systems in Transition: Sweden, 2005, WHO Regional Office for Europe on behalf of the European Observatory on Health Systems and Policies: Copenhagen.

38. Maier, C., et al., The reform of public health and the role of the sanitary-epidemiolgical services (sanepid) in the newly independent states. Meeting report, Bishkek, Kyrgyzstan, 1012 November 2008, 2009, World Health Organization Regional Office for Europe: Copenhagen. 
39. Breda, J., et al., Food security and healthier foods, in Facets of public health (in press), B. Rechel and M. McKee, Editors. 2013, World Health Organization, on behalf of the European Observatory on Health Systems and Policies: Copenhagen.

40. Martin-Moreno, J.M., et al., Cancer screening and health system resilience: Keys to protecting and bolstering preventive services during a financial crisis. Eur J Cancer, 2012. doi:10.1016/j.ejca.2012.02.060. 
Table 1 Expenditure on prevention and public health as $\%$ of total health expenditure, WHO European region, 2003-2010

\begin{tabular}{|c|c|c|c|c|c|c|c|c|}
\hline & 2003 & 2004 & 2005 & 2006 & 2007 & 2008 & 2009 & 2010 \\
\hline Albania & 1.57 & & & & 4.86 & 2.85 & 2.66 & 3.00 \\
\hline Armenia & 0.61 & 0.90 & 3.86 & 5.15 & 3.90 & 4.47 & 4.69 & \\
\hline Austria & 1.77 & 2.02 & 1.91 & 1.90 & 1.91 & 1.76 & 1.68 & 1.68 \\
\hline Belarus & & & & & & & & 3.81 \\
\hline Belgium & 2.27 & 2.26 & 2.16 & 2.36 & 2.73 & 3.16 & 2.74 & 2.74 \\
\hline $\begin{array}{ll}\text { Bosnia and } \\
\text { Herzegovina }\end{array}$ & & 2.70 & 2.69 & 2.67 & 2.35 & 2.63 & 1.86 & 2.43 \\
\hline Bulgaria & 3.45 & 3.86 & 3.01 & 3.45 & 3.86 & 4.10 & 3.46 & 3.46 \\
\hline Croatia & 0.00 & 0.00 & 0.00 & 0.00 & 0.00 & 0.00 & 0.65 & 0.68 \\
\hline Cyprus & 0.58 & 0.55 & 0.55 & 0.61 & 0.64 & 0.64 & 0.69 & 0.71 \\
\hline Czech Republic & 1.68 & 1.96 & 1.67 & 2.08 & 2.19 & 2.59 & 2.60 & 2.60 \\
\hline Denmark & 2.26 & 2.20 & 2.12 & 2.02 & 0.89 & 0.92 & 2.16 & 2.16 \\
\hline Estonia & 2.19 & 1.97 & 2.31 & 2.54 & 2.70 & 2.71 & 2.32 & 2.90 \\
\hline Finland & 4.81 & 4.89 & 5.05 & 5.10 & 5.40 & 5.42 & 5.26 & 5.25 \\
\hline France & 2.02 & 2.04 & 1.97 & 1.95 & 1.98 & 1.96 & 2.15 & 2.15 \\
\hline Georgia & 2.20 & 2.27 & 1.80 & 1.12 & 1.15 & 0.64 & 1.20 & 1.61 \\
\hline Germany & 3.23 & 3.26 & 3.23 & 3.29 & 3.51 & 3.59 & 3.54 & 3.54 \\
\hline Hungary & 4.77 & 4.30 & 4.25 & 4.06 & 4.00 & 3.86 & 4.25 & 4.25 \\
\hline Iceland & 1.39 & 1.45 & 1.51 & 1.49 & 1.58 & 1.54 & 1.43 & 1.44 \\
\hline Ireland & 2.32 & 2.96 & 2.96 & 3.00 & 2.95 & 2.97 & 2.98 & 2.97 \\
\hline Israel & 0.92 & 0.85 & 0.77 & 0.70 & 0.65 & 0.66 & 0.66 & 0.64 \\
\hline Italy & 0.71 & 0.62 & 0.56 & 0.56 & 0.60 & 0.62 & 0.61 & 0.62 \\
\hline Kyrgyzstan & & 2.20 & & 2.38 & 2.97 & 4.73 & 4.07 & 4.06 \\
\hline Latvia & 2.73 & 0.98 & 0.25 & 2.86 & 1.40 & 1.43 & 2.90 & 2.90 \\
\hline Lithuania & 3.42 & 1.72 & 1.69 & 1.18 & 1.74 & 1.17 & 1.13 & 1.13 \\
\hline Luxembourg & 1.77 & 1.47 & 2.06 & 1.68 & 1.90 & 1.72 & 1.75 & 1.75 \\
\hline Malta & 1.59 & 1.52 & 1.43 & 1.33 & 1.45 & 1.13 & 1.32 & 1.33 \\
\hline Montenegro & & 0.57 & 0.56 & 0.68 & & & & \\
\hline Netherlands & 4.89 & 4.49 & 4.33 & 4.58 & 4.66 & 4.51 & 4.01 & 3.85 \\
\hline Norway & 1.93 & 1.94 & 1.91 & 1.90 & 1.99 & 2.07 & & 2.11 \\
\hline Poland & 3.30 & 1.68 & 2.28 & 2.31 & 2.22 & 2.19 & 2.14 & 2.14 \\
\hline Portugal & 1.97 & 1.89 & 1.94 & 1.66 & 1.66 & 1.79 & 1.80 & 1.80 \\
\hline
\end{tabular}




\begin{tabular}{|l|l|l|l|l|l|l|l|l|}
\hline $\begin{array}{l}\text { Republic } \\
\text { Moldova }\end{array}$ & & & & & & & 4.35 & 7.56 \\
\hline Romania & 6.16 & 6.63 & 6.73 & 5.32 & 6.58 & 5.80 & 8.17 & 8.17 \\
\hline Serbia & 8.70 & 8.02 & 7.43 & 7.33 & 7.05 & 6.68 & 7.49 & 6.33 \\
\hline Slovakia & 1.64 & 2.73 & 2.28 & 4.29 & 4.71 & 4.61 & 4.62 & 4.61 \\
\hline Slovenia & 3.42 & 3.65 & 3.54 & 3.58 & 3.72 & 3.63 & 3.57 & 3.58 \\
\hline Spain & 2.23 & 2.25 & 2.27 & 2.29 & 2.37 & 2.27 & 2.58 & 2.58 \\
\hline Sweden & 3.10 & 3.06 & 3.29 & 3.07 & 3.34 & 3.45 & 3.64 & 3.63 \\
\hline Switzerland & 2.28 & 2.20 & 2.18 & 2.16 & 2.32 & 2.47 & 2.52 & 2.52 \\
\hline Tajikistan & 0.94 & 0.92 & 1.32 & & 2.19 & 3.03 & 2.78 & 2.84 \\
\hline Turkey & 4.67 & 5.11 & 4.97 & 4.91 & 5.38 & 5.57 & 5.54 & 5.54 \\
\hline Ukraine & 3.68 & 3.68 & 3.47 & 3.65 & 3.50 & 3.39 & 3.08 & 3.16 \\
\hline
\end{tabular}

Source: [11]

Note: No data available for Andorra, Azerbaijan, Greece, Kazakhstan, Monaco, the Russian Federation, San Marino, Macedonia, Turkmenistan, United Kingdom and Uzbekistan. 
Table 2 Expenditure on prevention and public health per capita at Purchasing

Power Parity (National Currency Unit per US\$), WHO European region, 2003-2010

\begin{tabular}{|c|c|c|c|c|c|c|c|c|}
\hline & 2003 & 2004 & 2005 & 2006 & 2007 & 2008 & 2009 & 2010 \\
\hline Albania & 5.1 & & & & 24.0 & 15.9 & 15.7 & 17.3 \\
\hline Armenia & 1.0 & 1.7 & 7.7 & 10.3 & 8.5 & 10.3 & 11.5 & \\
\hline Austria & 56.7 & 68.4 & 66.3 & 70.6 & 74.0 & 72.8 & 72.2 & 73.9 \\
\hline Belarus & & & & & & & & 30.0 \\
\hline Belgium & 69.0 & 71.4 & 69.7 & 77.4 & 93.8 & 117.4 & 108.4 & 110.5 \\
\hline $\begin{array}{l}\text { Bosnia and } \\
\text { Herzegovina }\end{array}$ & & 14.2 & 15.5 & 17.8 & 18.1 & 23.5 & 17.3 & 23.6 \\
\hline Bulgaria & 21.5 & 25.1 & 21.7 & 26.4 & 32.5 & 39.8 & 34.4 & 32.8 \\
\hline Croatia & & & & & & & 10.1 & 10.3 \\
\hline Cyprus & 8.5 & 8.1 & 8.5 & 10.1 & 11.1 & 11.9 & 12.9 & 13.0 \\
\hline $\begin{array}{l}\text { Czech } \\
\text { Republic }\end{array}$ & 22.5 & 27.1 & 24.6 & 32.3 & 36.3 & 47.7 & 54.8 & 53.3 \\
\hline Denmark & 65.3 & 68.7 & 68.9 & 72.1 & 33.2 & 36.9 & 93.7 & 97.8 \\
\hline Estonia & 16.5 & 16.9 & 19.1 & 24.3 & 29.8 & 35.5 & 31.1 & 35.5 \\
\hline Finland & 108.4 & 119.8 & 130.8 & 141.0 & 157.3 & 171.2 & 169.6 & 172.4 \\
\hline France & 60.4 & 63.3 & 64.9 & 67.9 & 72.6 & 74.6 & 85.2 & 86.3 \\
\hline Georgia & 5.2 & 5.9 & 5.4 & 3.8 & 4.4 & 2.8 & 5.8 & 8.4 \\
\hline Germany & 100.0 & 103.4 & 108.7 & 117.5 & 130.8 & 142.1 & 149.4 & 153.4 \\
\hline Hungary & 61.2 & 56.2 & 60.0 & 60.3 & 57.3 & 57.7 & 64.2 & 62.4 \\
\hline Iceland & 45.3 & 49.1 & 51.2 & 50.2 & 55.3 & 56.2 & 51.3 & 47.1 \\
\hline Ireland & 58.9 & 81.8 & 87.1 & 95.2 & 102.4 & 112.0 & 112.1 & 109.9 \\
\hline Israel & 15.8 & 15.3 & 13.7 & 13.0 & 12.9 & 13.7 & 14.0 & 14.1 \\
\hline Italy & 16.1 & 14.7 & 14.0 & 15.2 & 16.5 & 18.7 & 18.8 & 18.7 \\
\hline Kyrgyzstan & & 2.1 & & 2.8 & 4.0 & 6.1 & 6.0 & 5.7 \\
\hline Latvia & 17.8 & 7.5 & & 29.0 & 16.7 & 17.0 & 30.9 & 31.7 \\
\hline Lithuania & 26.8 & 12.8 & 14.1 & 11.8 & 19.8 & 15.3 & 14.6 & 14.7 \\
\hline Luxembourg & 82.4 & 78.3 & 111.8 & 102.3 & 114.8 & 104.7 & 115.3 & 117.7 \\
\hline Malta & 26.2 & 26.9 & 28.1 & 27.3 & 29.4 & 23.6 & 28.2 & 30.1 \\
\hline Montenegro & & 3.8 & 4.0 & 5.8 & & & & \\
\hline Netherlands & 151.6 & 148.7 & 149.6 & 169.6 & 183.8 & 190.9 & 195.8 & 193.8 \\
\hline Norway & 73.9 & 79.3 & 82.3 & 87.5 & 97.4 & 108.3 & & 114.6 \\
\hline Poland & 24.7 & 13.6 & 19.5 & 21.6 & 23.9 & 27.7 & 29.8 & 31.6 \\
\hline
\end{tabular}




\begin{tabular}{|c|c|c|c|c|c|c|c|c|}
\hline Portugal & 37.3 & 37.7 & 43.0 & 38.2 & 40.2 & 44.9 & 48.3 & 50.7 \\
\hline $\begin{array}{l}\text { Republic of } \\
\text { Moldova }\end{array}$ & & & & & & & 15.5 & 27.3 \\
\hline Romania & 25.2 & 31.8 & 34.8 & 30.2 & 44.1 & 47.2 & 66.9 & 66.3 \\
\hline Serbia & 53.1 & 54.0 & 57.4 & 65.1 & 73.8 & 79.5 & 87.1 & 74.0 \\
\hline Slovakia & 13.0 & 28.9 & 26.0 & 57.9 & 76.3 & 85.7 & 96.3 & 95.0 \\
\hline Slovenia & 60.4 & 67.7 & 69.9 & 75.2 & 78.9 & 88.6 & 91.0 & 91.4 \\
\hline Spain & 45.1 & 47.9 & 51.5 & 58.1 & 64.9 & 67.3 & 79.0 & 78.0 \\
\hline Sweden & 87.8 & 90.3 & 97.4 & 98.1 & 114.6 & 125.7 & 135.5 & 136.5 \\
\hline Switzerland & 85.3 & 85.9 & 86.7 & 91.0 & 105.2 & 120.9 & 128.6 & 135.9 \\
\hline Tajikistan & 0.5 & 0.5 & 1.0 & & 2.1 & 3.3 & 3.4 & 3.6 \\
\hline Turkey & 21.9 & 27.9 & 30.9 & 36.8 & 45.2 & 50.6 & 53.0 & 57.0 \\
\hline Ukraine & 11.5 & 12.8 & 12.5 & 14.6 & 15.6 & 16.5 & 15.2 & 16.4 \\
\hline
\end{tabular}

Source: Authors' calculations, based on [11]

Note: No data available for Andorra, Azerbaijan, Greece, Kazakhstan, Monaco, the Russian Federation, San Marino, Macedonia, Turkmenistan, United Kingdom and Uzbekistan. 